\title{
Mathematical Modelling for Thermal and Mechanical Design of Shell and Tube Type Gas Cooler Used in Transcritical $\mathrm{CO}_{2}$ Refrigeration System
}

\author{
Sandip Patil, Madhu Kasturi, Anil Acharya ${ }^{*}$, Ashok Pise \\ Department of Mechanical Engineering, Govt. College of Engineering, Karad, India
}

\section{Email address:}

aracharya@rediffmail.com (A. Acharya)

${ }^{*}$ Corresponding author

\section{To cite this article:}

Sandip Patil, Madhu Kasturi, Anil Acharya, Ashok Pise. Mathematical Modelling for Thermal and Mechanical Design of Shell and Tube Type Gas Cooler Used in Transcritical $\mathrm{CO}_{2}$ Refrigeration System. International Journal of Systems Science and Applied Mathematics. Vol. 2, No. 3, 2017, pp. 64-69. doi: 10.11648/j.ijssam.20170203.11

Received: May 15, 2017; Accepted: May 25, 2017; Published: July 12, 2017

\begin{abstract}
This paper is about Mathematical Modelling for Thermal and Mechanical Design of Shell and Tube type Gas Cooler used in Transcritical $\mathrm{CO}_{2}$ Refrigeration system. Transcritical refrigeration system refers to system whose condenser temperature is above critical temperature of refrigerant. To achieve it, the condenser in conventional refrigeration system is replaced by Gas Cooler where Refrigerant vapour is cooled sensibly without condensation. The gas cooler is used for cooling of refrigerant by using water as coolant. The temperature of refrigerant vapour coming out of compressor in transcritical system is more as compared to conventional refrigerant system. So gas cooler can be effectively used for heating of water. This paper describes a mathematical model that can be used in predicting the heat transfer performance of a shell and tube type Gas Cooler used in transcritical $\mathrm{CO}_{2}$ refrigeration system. The model uses Kern Method of Heat exchanger design. Given the fluid inlet and outlet temperatures flow rates of fluid \& fluid properties the model determines (a) the necessary heat transfer surface area, (b) Outside and inside heat transfer coefficient, (c) overall heat transfer coefficient, (d) Pressure drop on shell and tube side, (e) It also determines mechanical design parameters such as shell O. D, Shell thickness, Tube sheet thickness, Flange thickness.
\end{abstract}

Keywords: Gas Cooler, Transcritical, $\mathrm{CO}_{2}$, Refrigeration, Tube Sheet Thickness

\section{Introduction}

In the last few years researchers came to know about the adverse effect of refrigerants on environment i.e. global warming and ozone depletion potential as these are adverse effects government added restrictions on use of such refrigerant who causes the global warming and ozone depletion, so industries are in search of new and natural refrigerant which has low global warming and less ozone depletion potential. In this regard, $\mathrm{CO}_{2}$ is one of the refrigerants, which has zero ozone depletion potential and less value of global warming potential.

$\mathrm{CO}_{2}$ is having less value of critical temperature and pressure so getting less temperature range for application and restricted to $31^{\circ} \mathrm{C}$ to use $\mathrm{CO}_{2}$ for wide range of temperature to operate the system at pressure above critical point pressure i.e. above 73 bar as the pressure of the system is above critical point the condensation is not possible at pressure above critical pressure so in $\mathrm{CO}_{2}$ transcritical Refrigeration system condenser is replaced by gas cooler.

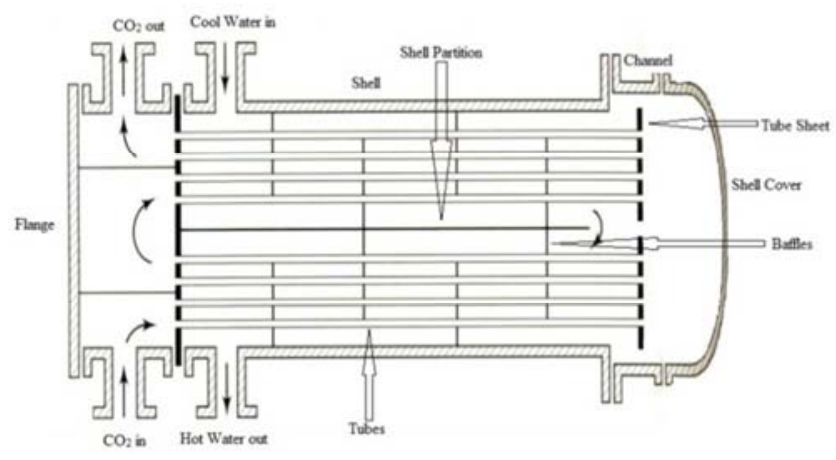

Figure 1. Constructional features of Gas Cooler. 
In this paper Shell and Tube type Gas Cooler used in transcritical $\mathrm{CO}_{2}$ refrigeration system is modelled using kern method as shown in figure 1. The various mathematical model used for design of shell and tube type gas cooler is explained in below section.

\section{Method of Design}

(1) Formulation of mathematical models for thermal and mechanical Design

(2) Calculation of different design parameters

(3) Selection of required parameters from standard charts and tables

(4) Final design of shell and tube gas cooler

\section{Mathematical Models for Thermal Design}

\subsection{Heat Duty of Heat Exchanger (Q)}

In the shell-and-tube condenser the water flows outside the tubes and refrigerant flows inside the tubes through the shell.

Heat duty of Heat Exchanger (Q) by performing Energy Balance

$$
\text { Heat Duty }(Q)=\dot{\mathrm{m}}_{\mathrm{w}} \times \mathrm{C}_{\mathrm{p}} \times\left(\mathrm{T}_{\mathrm{w} 2}-\mathrm{T}_{\mathrm{w} 1}\right)
$$

By considering uncertainty in heat load multiply Heat Duty by 1.25 to compensate Uncertainty of Heat Duty Due change inlet temperature of Cold fluid or Hot Fluid

$$
\text { Corrected Heat Duty }\left(\mathrm{Q}_{\text {cor }}\right)=1.25 \times \mathrm{Q}
$$

Where $\dot{\mathrm{m}}_{\mathrm{w}}$ is mass flow rate of water $(\mathrm{kg} / \mathrm{s})$ and $\mathrm{C}_{\mathrm{p}}$ is Specific Heat of water $\left(\mathrm{J} / \mathrm{kg}^{\circ} \mathrm{C}\right), \mathrm{T}_{\mathrm{w} 1}$ and $\mathrm{T}_{\mathrm{w} 2}$ are respectively inlet and outlet temperature of water.

\subsection{Log-Mean Temperature Difference (LMTD)}

The log mean temperature difference $\Delta \mathrm{T}_{\mathrm{m}}$ for counter current flow is determined by:

$$
\mathrm{LMTD}=\left(\frac{\Delta \mathrm{T}_{1} . \Delta \mathrm{T}_{2}}{\ln \left(\frac{\Delta \mathrm{T1}}{\Delta \mathrm{T} 2}\right)}\right)
$$

Where $\Delta \mathrm{T}_{1}=\left(\mathrm{T}_{\mathrm{c} 1}-\mathrm{T}_{\mathrm{w} 2}\right) \& \Delta \mathrm{T}_{2}=\left(\mathrm{T}_{\mathrm{c} 2}-\mathrm{T}_{\mathrm{w} 1}\right), \mathrm{T}_{\mathrm{w} 1}$ and $\mathrm{T}_{\mathrm{w} 2}$ are respectively the inlet and outlet temperature for water, $\mathrm{Tc}_{1}$ and $\mathrm{Tc}_{2}$ are the inlet and outlet temperature for $\mathrm{CO}_{2}$ respectively

\subsection{Correction Factor}

In design the heat exchangers, a correction factor is applied to the log mean temperature difference (LMTD) to allow for the departure from true counter current flow to determine the true temperature difference. Correction factor for LMTD can be calculated from the Standard Graph Available in Textbook D. Q Kern Process Heat Transfer. Before going to calculation of correction factor one must decide the Number of shell passes \& Number of tube passes and two factors i.e. ' $R$ ' and ' $S$ ', they can be defined as follows-

$$
\begin{aligned}
& R=\left(\frac{T_{w 1}-T_{w 2}}{T_{c 2}-T_{c 1}}\right) \\
& S=\left(\frac{T_{c 2}-T_{c 1}}{T_{w 1}-T_{c 1}}\right)
\end{aligned}
$$

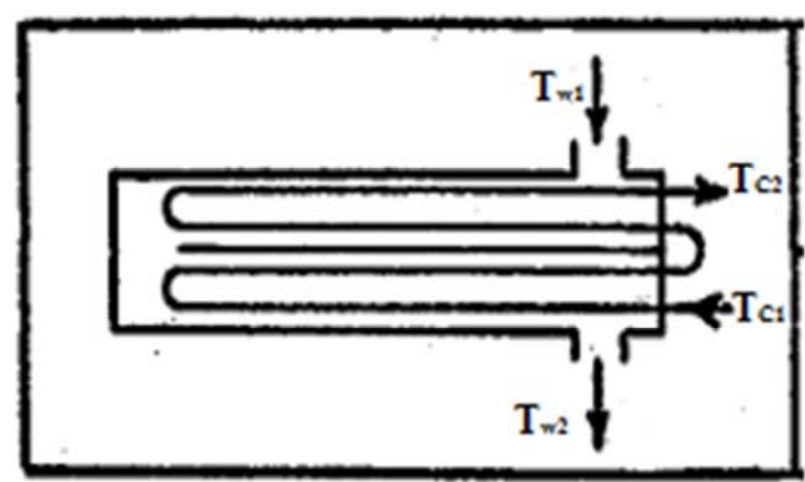

Figure 2. Flow arrangement.

The value of correction factor obtained from graph using $\mathrm{R}=0.711 \mathrm{~S}=0.789$ and 2 shell passes and 4 tube passes is 0.78

\subsection{Heat Transfer Area}

The heat transfer area (A) of the shell-and-tube condenser is computed by:

$$
\begin{gathered}
\mathrm{Q}=\mathrm{U}_{\text {ass }} \times \mathrm{A} \times \mathrm{LMTD} \times \mathrm{Ft} \\
\therefore \mathrm{A}=\left(\frac{\mathrm{Q}}{\mathrm{U}_{\text {ass }} \times \text { LMTD } \times \mathrm{Ft}}\right)
\end{gathered}
$$

Where Ft is LMTD correction factor and Uss is assumed overall heat transfer coefficient $\left(\mathrm{w} / \mathrm{m}^{2} \mathrm{k}\right)$.

\subsection{Number of Tubes (Nt)}

The Number of tubes required for required surface area is given by:

$$
\mathrm{Nt}=\left(\frac{\mathrm{A}}{\pi \times \mathrm{D}_{\mathrm{o}} \times \mathrm{L}}\right)
$$

Where $\mathrm{D}_{0}$ is outside diameter of tube (meter) and $\mathrm{L}$ is length of tube (meter).

\subsection{Inside Heat Transfer Coefficient}

Inside Heat transfer Coefficient Using sieder-Tate equation is given by:

$$
\mathrm{j}_{\mathrm{H}}=\left(\frac{\mathrm{h}_{\mathrm{i}} \times D_{\mathrm{i}}}{\mathrm{K}_{\mathrm{c}}}\right) \times\left(\frac{\mu \times C_{\mathrm{pc}}}{\mathrm{k}_{\mathrm{c}}}\right)^{\frac{-1}{3}} \times\left(\frac{\mu}{\mu_{\mathrm{w}}}\right)^{-0.14}
$$

$\mathrm{j}_{\mathrm{H}}$ can be calculated from Standard graph by knowing the Reynolds number below graph shows the value $\mathrm{jh}$ corresponding to different Re from below graph $\mathrm{j}_{\mathrm{H}}=70$ for Reynolds Number $=19339.98$

Where $h_{i}$ is inside heat transfer coefficient $\left(w / m^{2} k\right),\left(\mu_{w}\right)$ is 
Dynamic viscosity at wall temperature $\left(\mathrm{N} . \mathrm{S} / \mathrm{m}^{2}\right), \mu$ is Dynamic viscosity at bulk mean temperature $\left(\mathrm{N} . \mathrm{S} / \mathrm{m}^{2}\right), \mathrm{C}_{\mathrm{pc}}$ is Specific Heat of $\mathrm{CO}_{2}\left(\mathrm{~J} / \mathrm{kg}^{0} \mathrm{~K}\right), \mathrm{Kc}$ is Thermal Conductivity of $\mathrm{CO}_{2}\left(\mathrm{~W} / \mathrm{m}^{0} \mathrm{~K}\right)$ and $\mathrm{Di}$ is inside diameter of tube.

\subsection{Shell Side Heat Transfer Coefficient $h_{o}$}

For calculation of $h_{0}$ first one has to calculate Re for Shell side fluid for that purpose one must know the Mass velocity (Gs) of shell side fluid, Cross flow area $\left(a_{c}\right)$.

For calculating Mass velocity equivalent diameter of Shell (De) is required.

Equivalent diameter of Shell $(\mathrm{De})=\left(\frac{4 \times\left((\mathrm{Pt})^{2}-\frac{\pi}{4} \times \mathrm{Do}^{2}\right)}{\pi \times \mathrm{Do}}\right)$ for square pitch

Tube clearance $(\mathrm{C})=(\mathrm{Pt}-\mathrm{Do})$

Shell side cross flow area $\left(\mathrm{a}_{\mathrm{s}}\right)=\left(\frac{\mathrm{C} \times \mathrm{B} \times \mathrm{Ds}}{\mathrm{P}_{\mathrm{t}}}\right)$

Mass Velocity $(\mathrm{Gs})=\left(\frac{\dot{\mathrm{m}}_{\mathrm{w}}}{\mathrm{a}_{\mathrm{s}} \mathrm{x} \rho_{\mathrm{w}}}\right)$

Reynolds number for shell side fluid $(\mathrm{Re})_{\mathrm{s}}=\left(\frac{\mathrm{G}_{\mathrm{s}} \times \mathrm{D}_{\mathrm{e}}}{v_{\mathrm{w}}}\right)$

For calculation of outside heat Transfer Coefficient $\left(h_{o}\right)$ sieder-Tate equation is used (Ref. D. Q Kern Process Heat transfer Text book)

$$
\mathrm{j}_{\mathrm{H}}=\left(\frac{\mathrm{h}_{\mathrm{x}} \mathrm{D}_{\mathrm{e}}}{\mathrm{K}_{\mathrm{w}}}\right) \times\left(\frac{\mu \times \mathrm{C}_{\mathrm{pw}}}{\mathrm{k}_{\mathrm{w}}}\right)^{\frac{-1}{3}} \times\left(\frac{\mu}{\mu_{\mathrm{w}}}\right)^{-0.14}
$$

Where $\mathrm{Kw}$ is thermal conductivity of water $\left(\mathrm{w} / \mathrm{m}^{\circ} \mathrm{C}\right), \mathrm{h}_{\mathrm{o}}$ is outside heat transfer coefficient, $\mathrm{G}_{\mathrm{s}}$ is Mass flow Velocity $(\mathrm{m} / \mathrm{sec}), \mathrm{a}_{\mathrm{c}}$ is cross flow area, $\mathrm{Pt}$ is pitch of tube (meter), B is baffle spacing (meter), Ds is shell inside diameter (meter), $\rho_{\mathrm{w}}$ is density of water $\left(\mathrm{kg} / \mathrm{m}^{3}\right)$ and $v_{\mathrm{w}}$ is Kinematic Viscosity $\left(\mathrm{m}^{2} / \mathrm{s}\right)$.

\subsection{Overall Heat Transfer Coefficient}

Overall heat transfer coefficient $U$ based on inside surface area depends on the tube inside diameter, tube outside diameter, tube side convective coefficient, shell side convective coefficient, tube side fouling resistance, shell side fouling resistance, and tube material is given by:

$$
\frac{1}{\mathrm{UA}_{\mathrm{i}}}=\left(\frac{1}{\mathrm{~A}_{\mathrm{i}} \times \mathrm{h}_{\mathrm{i}}}\right)+\left(\frac{1}{\mathrm{~A}_{\mathrm{o}} \times \mathrm{h}_{\mathrm{o}}}\right)
$$

To determine \% error between assumed value of overall heat transfer coefficient $U_{\text {ass }}$ and Actual value of overall Heat transfer coefficient $U_{\text {act }}$

$$
\% \text { Error }=\left(\frac{\mathrm{U}_{\text {ass }}-\mathrm{U}_{\text {act }}}{\mathrm{U}_{\text {ass }}}\right)
$$

\subsection{Pressure Drop}

a) Tube side pressure drop

It consists of two type of pressure losses i.e. frictional pressure drop $(\Delta \mathrm{P})_{\mathrm{t}}$ due to friction between fluid and tube wall and return losses $(\Delta \mathrm{P})_{\mathrm{rt}}$ due to change in flow direction of the tube side fluid

$$
\text { Pressure drop due to friction }(\Delta \mathrm{P})_{\mathrm{t}}=\left(\frac{f \times \mathrm{Lx}\left(\mathrm{G}_{\mathrm{t}}\right)^{2} \mathrm{~N}_{\mathrm{p}} \times \rho_{\mathrm{c}}}{\mathrm{D}_{\mathrm{i}} \times(\mathrm{S} . \mathrm{G})_{\mathrm{c}} \times \emptyset_{\mathrm{t}}}\right)
$$

Friction factor (f) is calculated from standard graph available corresponding to Reynolds number.

Return loss $(\Delta \mathrm{P})_{\mathrm{rt}}=(2 \times \mathrm{Np}-1.5)\left(\frac{\left(\mathrm{G}_{\mathrm{t}}\right)^{2} \times \rho_{\mathrm{c}}}{(\mathrm{S} . \mathrm{G})_{\mathrm{c}}}\right)$

Total pressure drop in tubes $=\left[(\Delta \mathrm{P})_{\mathrm{t}}+(\Delta \mathrm{P})_{\mathrm{rt}}\right]$

Where $f_{t}$ is friction factor for tubes, $G_{t}$ is tube side Mass Velocity $(\mathrm{m} / \mathrm{s}), \mathrm{N}_{\mathrm{p}}$ is number of tube passes, $\rho_{\mathrm{c}}$ is density of $\mathrm{CO}_{2}\left(\mathrm{~kg} / \mathrm{m}^{3}\right), \mathrm{S} . \mathrm{G}$ is Specific Gravity of water and $\emptyset_{\mathrm{t}}\left(\frac{\mu}{\mu_{\mathrm{w}}}\right)$.

b) Shell side pressure drop

Pressure Drop due to friction

$$
(\Delta \mathrm{P})_{\mathrm{s}}=\left(\frac{f \times \mathrm{D}_{\mathrm{s}} \times\left(\mathrm{G}_{\mathrm{s}}\right)^{2}\left(\mathrm{~N}_{\mathrm{b}}+1\right) \times \rho_{\mathrm{w}}}{\mathrm{D}_{\mathrm{e}} \times(\mathrm{S} . \mathrm{G})_{\mathrm{w}} \times \emptyset_{\mathrm{t}}}\right)
$$

Friction factor (f) calculated from standard graph available corresponding to Reynolds number.

Return losses due to change in flow direction of shell side fluid

$$
(\Delta \mathrm{P})_{\mathrm{rs}}=(2 \times \mathrm{Np}-1.5)\left(\frac{\left(\mathrm{G}_{\mathrm{s}}\right)^{2} \times \rho_{\mathrm{w}}}{(\mathrm{S} . \mathrm{G})_{\mathrm{w}}}\right)
$$

Total pressure drop in Shell $=\left[(\Delta \mathrm{P})_{\mathrm{s}}+(\Delta \mathrm{P})_{\mathrm{rs}}\right]$

\section{Mathematical Models for Mechanical Design}

Shell Thickness $\left(t_{s}\right)$

The shell thickness $\left(t_{s}\right)$ can be calculated from the equation below based on the maximum allowable stress and corrected for joint efficiency

$$
\mathrm{t}_{\mathrm{s}}=\left(\frac{\mathrm{P} \times \mathrm{Ds}}{\mathrm{f} \times \mathrm{J}-0.6 \mathrm{P}}\right)+\mathrm{C}_{\mathrm{a}}
$$

O. D of Shell $\left(\mathrm{D}_{\mathrm{so}}\right)=\mathrm{I}$. D of Shell $+2 \mathrm{x}$ thickness of shell

$$
=254+2 \times 35=324 \mathrm{~mm}
$$

324 is selected as nominal diameter of Shell from standard IS 2844-1967

Where $P$ is Design pressure $\left(\mathrm{N} / \mathrm{mm}^{2}\right)$, $\mathrm{f}$ is Maximum allowable stress of the material used for construction $\left(\mathrm{N} / \mathrm{mm}^{2}\right), J$ is Joint efficiency (usually varies from 0.7 to 0.9 ) and $\mathrm{C}_{\mathrm{a}}$ corrosion allowance.

Tube Sheet Thickness

The minimum tube-sheet thickness (TEMA standard) to 'resist bending' can be calculated by,

$$
\mathrm{t}_{\mathrm{ts}}=\frac{\mathrm{FxGp}}{3} \times\left(\sqrt{\frac{\mathrm{p}}{\mathrm{kxf}}}\right)
$$

Where $\mathrm{f}$ is for fixed tube sheet, $\mathrm{G}_{\mathrm{p}}$ is diameter over which pressure is acting ( for fixed tube sheet it is equal to shell inside diameter ), $\mathrm{P}$ is shell pressure $\left(\mathrm{N} / \mathrm{mm}^{2}\right)$ and $\mathrm{K}$ is Mean ligament efficiency.

For square pitch $\mathrm{K}$ is given by:

$$
\mathrm{K}=1-\left(\frac{0.785}{\left(\frac{\mathrm{PT}}{\mathrm{do}}\right)}\right)
$$

For $19 \mathrm{~mm}$ outside diameter of tube the minimum tube sheet thickness is $15 \mathrm{~mm}$, as calculated tube sheet thickness 
is greater than $15 \mathrm{~mm}$ design is satisfied.

Gasket Design

A preliminary estimation of gaskets is done using following expression:

Residual gasket force $=$ Gasket seating force-(Hydrostatic pressure force)

The residual gasket force should be greater than that required to prevent the leakage of the internal fluid. This condition results the final expression in the form of

$$
\left(\frac{D_{\mathrm{OG}}}{D_{\mathrm{IG}}}\right)=\left(\sqrt{\frac{\mathrm{Y}-\mathrm{P} \times \mathrm{m}}{\mathrm{Y}-\mathrm{P}(\mathrm{m}+1)}}\right)
$$

Where $\mathrm{m}$ is gasket factor for Flat iron jacketed asbestos ( $\mathrm{m}$
= 3.75), $\mathrm{Y}$ is Minimum Design seating stress (for Flat iron jacketed asbestos $\mathrm{Y}=52.48 \mathrm{~N} / \mathrm{mm}^{2}$ ), $\mathrm{D}_{\mathrm{OG}}$ is Outside diameter of Gasket (mm), $D_{\text {IG }}$ is inside diameter of Gasket (mm)

Gasket Width $(\mathrm{N})=\left(\mathrm{D}_{\mathrm{OG}}-\mathrm{D}_{\mathrm{IG}}\right) / 2$

Mean Gasket Diameter $(\mathrm{G})=\left(\mathrm{D}_{\mathrm{OG}}+\mathrm{D}_{\mathrm{IG}}\right) / 2$

Basic Gasket Seating Width $\left(\mathrm{b}_{\mathrm{o}}\right)=(\mathrm{N} / 2)$

Effective Gasket Seating Width $(\mathrm{b})=0.5 \sqrt{\mathrm{b}_{\mathrm{o}}}$

\section{Results}

By using the mathematical models mentioned above the different parameters are calculated and tabulated in subsequent tables. For calculation of parameters some parameters are directly taken from standard tables and standard graphs.

Table 1. Input parameters.

\begin{tabular}{lll}
\hline Sr. no & Input parameters & Value \\
\hline 1 & Inlet temperature of cold fluid (Water) in ${ }^{\circ} \mathrm{C}$ & $23^{\circ} \mathrm{C}$ \\
2 & Outlet temperature of Cold fluid (Water) in ${ }^{\circ} \mathrm{C}$ & $55^{\circ} \mathrm{C}$ \\
3 & Inlet temperature of Hot fluid (Carbon Dioxide) in ${ }^{\circ} \mathrm{C}$ & $80^{\circ} \mathrm{C}$ \\
4 & Outlet temperature of Hot fluid (Carbon Dioxide) in ${ }^{\circ} \mathrm{C}$ & $35^{\circ} \mathrm{C}$ \\
5 & Pressure in Gas cooler & $90 \mathrm{bars}$ \\
6 & Mass flow rate of water(mw) & $0.0389 \mathrm{~kg} / \mathrm{s}$ \\
\hline
\end{tabular}

Table 2. Fluid properties.

\begin{tabular}{ll}
\hline Fluid properties of hot fluid & \\
Properties of Hot Fluid (Carbon Dioxide at mean bulk Temperature of $\mathbf{5 7 . 5} \mathbf{C}^{\circ}$ and at working pressure of 90 bars) \\
\hline 1. Density $(\rho c)$ & $247.8 \mathrm{~kg} / \mathrm{m}^{3}$ \\
2. Specific Heat $(\mathrm{Cpc})$ & $2707 \mathrm{~J} / \mathrm{kg}^{\circ} \mathrm{C}$ \\
3. Thermal Conductivity $(\mathrm{Kc})$ & $0.03629 \mathrm{~W} / \mathrm{m}^{\circ} \mathrm{C}$ \\
4. Dynamic viscosity $\left({ }^{\circ} \mathrm{C}\right)$ & $21.86 \times 10-6 \mathrm{~N} . \mathrm{S} / \mathrm{m}^{2}$ \\
5. Kinematic Viscosity $(v \mathrm{c})$ & $0.0886 \times 10-6 \mathrm{~m}^{2} / \mathrm{s}$ \\
6. Prandtl number $(\operatorname{Pr}) \mathrm{c}$ & 1.62 \\
7. Specific Gravity $(\mathrm{S} . \mathrm{G}) \mathrm{c}$ & 0.2478 \\
Fluid properties of Cold Fluid & \\
Properties of Cold Fluid $\left(\right.$ Water at mean bulk Temperature of $\left.39^{\circ} \mathrm{C}\right)$ & \\
Density $\left(\rho_{\mathrm{w}}\right)$ & $992.22 \mathrm{~kg} / \mathrm{m}^{3}$ \\
Specific Heat $\left(\mathrm{C}_{\mathrm{pw}}\right)$ & $4179 \mathrm{~J} / \mathrm{kg}^{\circ} \mathrm{C}$ \\
Thermal Conductivity $\left(\mathrm{K}_{\mathrm{w}}\right)$ & $0.631 \mathrm{~W} / \mathrm{m}^{\circ} \mathrm{C}$ \\
Dynamic viscosity $\left(\mu_{\mathrm{w}}\right)$ & $0.000652 \mathrm{~N} . \mathrm{S} / \mathrm{m}^{2}$ \\
Kinematic Viscosity $\left(v_{\mathrm{w}}\right)$ & $0.6581 \times 10^{-6} \mathrm{~m}^{2} / \mathrm{s}$ \\
Prandtl number $\left(\mathrm{P}_{\mathrm{r}}\right)_{\mathrm{w}}$ & 4.16 \\
Specific Gravity $(\mathrm{S} . \mathrm{G})_{\mathrm{w}}$ & 1 \\
\hline
\end{tabular}

Table 3. Parameters calculated using mathematical modelling.

\begin{tabular}{|c|c|c|c|c|}
\hline Sr. No & Calculated parameters & Symbol & units & Numerical value \\
\hline 1 & Heat duty & Q & watts & 5202 \\
\hline 2 & Corrected heat duty & $\mathrm{Q}_{\mathrm{c}}$ & watts & 6502 \\
\hline 3 & Mass flow rate of $\mathrm{CO} 2$ & $\dot{\mathrm{m}}_{\mathrm{c}}$ & $\mathrm{Kg} / \mathrm{sec}$ & 0.0534 \\
\hline 4 & LMTD & LMTD & - & 17.71 \\
\hline 5 & Correction factor for LMTD & $\mathrm{Ft}$ & - & 0.78 \\
\hline 6 & Heat transfer area & $\mathrm{A}_{\mathrm{s}}$ & $\mathrm{m}^{2}$ & 2.35 \\
\hline 7 & No of tubes & $\mathrm{N}_{\mathrm{t}}$ & - & 40 \\
\hline 8 & Tube side velocity & $\mathrm{V}$ & $\mathrm{m} / \mathrm{s}$ & 0.1056 \\
\hline 9 & Reynolds no for tube side fluid & $(\operatorname{Re})_{t}$ & - & 19339.98 \\
\hline 10 & Inside heat transfer coefficient & $\mathrm{h}_{\mathrm{i}}$ & $\mathrm{w} / \mathrm{m}^{2} \mathrm{k}$ & 185.67 \\
\hline 11 & Equivalent diameter of shell & $\mathrm{D}_{\mathrm{e}}$ & $\mathrm{mm}$ & 24.08 \\
\hline 12 & Shell side cross flow area & $\mathrm{A}_{\mathrm{s}}$ & $\mathrm{m}^{2}$ & 0.0136 \\
\hline 13 & Mass flow Velocity & $\mathrm{G}_{\mathrm{s}}$ & $\mathrm{m} / \mathrm{sec}$ & 0.00287 \\
\hline 14 & Reynolds no for shell side fluid & $(\mathrm{Re})_{\mathrm{s}}$ & - & 1109.10 \\
\hline 15 & Outside heat transfer coefficient & $\mathrm{h}_{\mathrm{o}}$ & $\mathrm{w} / \mathrm{m}^{2} \mathrm{k}$ & 725.33 \\
\hline 16 & Overall heat transfer coefficient & $\mathrm{U}$ & $\mathrm{w} / \mathrm{m}^{2} \mathrm{k}$ & 152.30 \\
\hline
\end{tabular}




\begin{tabular}{lllll}
\hline Sr. No & Calculated parameters & Symbol & units & Numerical value \\
\hline 16 & Tube side pressure drop & $\Delta \mathrm{p}_{\mathrm{t}}$ & $\mathrm{N} / \mathrm{m}^{2}$ & 191.74 \\
17 & Shell side pressure drop & $\Delta \mathrm{p}_{\mathrm{s}}$ & $\mathrm{N} / \mathrm{m}^{2}$ & 7.12 \\
18 & Shell thickness \& shell O. D & $\mathrm{t}_{\mathrm{s}} \& \mathrm{D}_{\mathrm{s}}$ & $\mathrm{mm}$ & 35,324 \\
19 & Shell cover thickness & $\mathrm{t}_{\mathrm{h}}$ & $\mathrm{mm}$ & 25.34 \\
20 & Channel cover thickness & $\mathrm{t}_{\mathrm{cc}}$ & $\mathrm{mm}$ & 19 \\
21 & Tube sheet thickness & $\mathrm{t}_{\mathrm{s}}$ & $\mathrm{mm}$ & 35.81 \\
22 & Nozzle thickness calculations & $\mathrm{t}_{\mathrm{n}}$ & $\mathrm{mm}$ & 3.33 \\
23 & Gasket diameter & $\mathrm{G}$ & $\mathrm{mm}$ & 340 \\
24 & Gasket width & $\mathrm{N}$ & $\mathrm{mm}$ & 85.4 \\
25 & Flange thickness & $\mathrm{t}_{\mathrm{f}}$ & $\mathrm{mm}$ & 129 \\
\hline
\end{tabular}

Table 4. Parameters directly selected from standard charts for modelling.

\begin{tabular}{lll}
\hline Sr. No & Selected parameters & Description and value \\
\hline 1 & Tube material & Stainless steel \\
2 & Outside diameter of tube & $19.05 \mathrm{~mm}$ \\
3 & Wall thickness of tube & $16 \mathrm{BWG}(1.651 \mathrm{~mm})$ \\
4 & Inside diameter of tube & $16.1036 \mathrm{~mm}$ \\
5 & Length of tube & $1000 \mathrm{~mm}$ \\
6 & Type of shell \& Tube H. E & Fixed tube sheet type H. E (2 shell \& 4 tube passes) \\
7 & Factor for sider tate equation for inside heat transfer coefficient $\left(\mathrm{j}_{\mathrm{H}}\right)$ & 70 \\
8 & Tube pitch $(\mathrm{Pt})$ & $2.54 \mathrm{~mm}$ \\
9 & Factor for sider tate equation for inside heat transfer coefficient $\left(\mathrm{j}_{\mathrm{H}}\right)$ & 17 \\
10 & Inside shell diameter $(\mathrm{Dsi})$ & $254 \mathrm{~mm}$ \\
11 & Type of baffle & Segmented baffle with $25 \%$ cut \\
12 & Tube side fluid & $\mathrm{CO} 2$ Due to high pressure \\
13 & Shell side fluid & Water \\
14 & No of baffles $\left(\mathrm{N}_{\mathrm{b}}\right)$ & 04 \\
15 & Friction factor for tube $(f \mathrm{t})$ & 0.03312 \\
16 & Friction factor for shell $(f \mathrm{~s})$ & 0.4752 \\
17 & Corrosion allowance $(\mathrm{Ca})$ & $1.5 \mathrm{~mm}$ carbon steel \\
18 & Permissible stress for Carbon steel $(\mathrm{f})$ & $100.6 \mathrm{~N} / \mathrm{mm}^{2}$ \\
\hline
\end{tabular}

\section{Conclusion}

When we compare the results of shell \& Tube heat exchanger used in conventional refrigeration system \& transcritical $\mathrm{CO}_{2}$ refrigeration system we found out that:

(1) Design pressure is higher in Gas Cooler so the thickness of shell, Tubes, flanges, tube sheet are higher than conventional shell and tube heat exchanger.

(2) Due to high pressure in $\mathrm{CO}_{2}$ refrigeration system the material used for construction of tube is stainless steel rather than copper and brass.

(3) The $\mathrm{CO}_{2}$ gas cooler is working under higher pressure than conventional shell and tube heat exchanger.

(4) As temperature of refrigerant vapour is higher than conventional refrigeration system gas cooler can be effectively used for water heating for domestic \& industrial purpose.

\section{Nomenclature}

$\begin{array}{ll}\mathrm{A}_{\mathrm{s}} & \text { Heat transfer area }\left(\mathrm{m}^{2}\right) \\ \mathrm{Nt} & \text { Number of tubes } \\ \mathrm{Q} & \text { Heat duty }(\mathrm{W}) \\ \mathrm{Q}_{\mathrm{c}} & \text { Corrected heat duty (W) }\end{array}$

$\dot{\mathrm{m}}_{\mathrm{c}}$

$\operatorname{Re}$

$\mathrm{h}_{\mathrm{i}}$

$\mathrm{h}_{\mathrm{o}}$

$\mathrm{G}_{\mathrm{s}}$

$\mathrm{U}$

$\mathrm{t}_{\mathrm{s}}$

$\mathrm{D}_{\mathrm{s}}$

$t_{h}$

$t_{\mathrm{cc}}$

$t_{\text {ts }}$

$\mu_{\mathrm{w}}$

$\mathrm{P}_{\mathrm{r}}$

S. G

Subscripts

c

w

e

i

o

t

$\mathrm{S}$
Mass flow rate of $\mathrm{CO} 2(\mathrm{Kg} / \mathrm{sec})$

Reynolds number

Inside heat transfer coefficient $\left(\mathrm{W} / \mathrm{m}^{2} \mathrm{k}\right)$

Outside heat transfer coefficient $\left(\mathrm{W} / \mathrm{m}^{2} \mathrm{k}\right)$

Mass flow Velocity $(\mathrm{m} / \mathrm{sec})$

Overall heat transfer coefficient $\left(\mathrm{W} / \mathrm{m}^{2} \mathrm{k}\right)$

Shell thickness (m)

Shell outer diameter $(\mathrm{m})$

Shell cover thickness (m)

Channel cover thickness (m)

Tube sheet thickness (m)

Dynamic viscosity (N. S/m²)

Prandtl number

Specific Gravity

$\mathrm{CO}_{2}$

Water

Equivalent

Inside

Outside

Tube side

Shell side 


\section{References}

[1] Y. T. Ge, S. A. Tassou, Dewa Santosa, K. Tsamos "Design optimisation of $\mathrm{CO}_{2}$ gas cooler/condenser in a refrigeration system" science Direct Applied Energy 160 (2015) 973-981.

[2] V. Perez-Garcia, J. M. Belman-Flores, J. Navarro-Esbri, C. Rubio Maya"Comparative study of transcritical vapor compression configurations Using Carbon dioxide as Refrigeration mode base on simulation" science Direct Applied Thermal Engineering 51 (2013) 1038 e1046.

[3] Aklilu Tesfamichael Bahetaa, Suhaimi Hassana, Allya Radzihan B Reduana, and Abraham D. Woldeyohannes "Performance investigation of transcritical carbon dioxide refrigeration cycle" ScienceDirect Procedia CIRP 26 (2015) $482-485$.

[4] Kenneth B. Madsen, Claus S. Poulsenb, Maike Wiesenfarth "Study of capillary tubes in a transcritical $\mathrm{CO}_{2}$ Refrigeration system" ScienceDirect International Journal of Refrigeration 28 (2005) 1212-1218.
[5] J M Belman-Flores, Vicente Perez-Garcia, Jean Fulbert ItunaYudonago, Jose Luis Rodriguez-Munoz, Jose de Jesus Ramírez-Minguela "General aspects of carbon dioxide as a refrigerant" Journal of Energy in Southern Africa, Vol 25 No 2 May 2014.

[6] Man-Hoe Kim, Jostein Pettersen, Clark W. Bullard "Fundamental process and system design issues in $\mathrm{CO}_{2}$ vapour compression systems" science Direct Progress in Energy and Combustion Science 30 (2004) 119-174.

[7] Shigeharu TAIRA "The Development of Heat Pump Water Heaters Using $\mathrm{CO}_{2}$ Refrigerant" DAIKIN Industries, Ltd., 1000-2 Aza-Ohtani, Okamoto-cho, Kusatsu, Shiga 525-8526.

[8] Charles R. Taylor, P. E. "Carbon Dioxide-Based Refrigerant Systems” ASHRAE Journal September 2002.

[9] Padalkar A. S, Kadam A. D. "Carbon Dioxide as Natural Refrigerant" International Journal of Applied Engineering Research, Dindigul Volume 1, No 2, 2010.

[10] C. P. Arora, Refrigeration and Air conditioning, Tata McGraw Hill Publication, New Delhi, 2009. 